\title{
Lack of antiphospolipid antibodies in long-term cardiac rheumatic fever
}

\author{
Jozélio Freire de Carvalho • \\ Cláudia Goldenstein-Schainberg
}

Received: 29 March 2011 / Accepted: 22 August 2011 / Published online: 1 September 2011

(C) Springer-Verlag 2011

\section{Dear Sir,}

Rheumatic fever (RF) has been linked with the presence of antiphospholipid syndrome [1], especially with antiphospholipid antibodies, represented by anticardiolipin in $40 \%$ of the patients [2] and anti- $\beta 2$-glicoprotein I antibodies in $24 \%$ of them [3]. However, there is no study in which all routine antiphospholipid antibodies were performed simultaneously in RF patients. Consequently, the objective of this study was to evaluate the frequency and clinical significance of three routine antiphospholipid antibodies in sera from patients with RF who had cardiac involvement.

All study participants met the modified Jones criteria for the diagnosis of RF [4]. This research is characterized as a descriptive cross-sectional study that was conducted in the Rheumatology Division, Hospital das Clínicas da Faculdade de Medicina, Universidade de São Paulo. The data regarding laboratory results from all $9 \mathrm{RF}$ patients were obtained from the patients' medical files. Using standard techniques, serum samples were tested for lupus anticoagulant (functional tests), IgM and IgG anticardiolipin (ELISA), and IgM and IgG anti- $\beta 2$-GPI (ELISA) [5, 6].

Mean age of RF patients was $23.9 \pm 6.8$ years; $56 \%$ were women and $67 \%$ Caucasian race. Mean disease duration was $10.8 \pm 6.9$ years. All patients had cardiac lesions, with $100 \%$ of mitral involvement. Polyarthritis was

JF Carvalho received grants from Federico Foundation and CNPq (300665/2009-1).

J. F. de Carvalho $(\varangle) \cdot$ C. Goldenstein-Schainberg

Rheumatology Division, Hospital das Clínicas da Faculdade de

Medicina da Universidade de São Paulo, Av. Dr. Arnaldo,

455-3o andar-Reumatologia, sala 3190, São Paulo,

SP 01246-903, Brazil

e-mail: jotafc@gmail.com observed in $67 \%$ and chorea in $34 \%$. In contrast to other studies, no patient had any sera positive for antiphospholipid antibodies such as IgG or IgM anticardiolipin, lupus anticoagulant, and IgG or IgM anti- $\beta 2$-GPI analyzed.

We were not able to demonstrate a relationship between antiphospholipid antibodies in RF patients who had cardiac involvement. Figueroa et al. [2] have shown that during active phase of RF, $80 \%$ of patients have positivity for anticardiolipin, while during inactive disease, only $40 \%$ have had these autoantibodies. Therefore, due to the absence of these antibodies in sera from our 9 patients with long-term $\mathrm{RF}$, it is reasonable to speculate that different phases of this disease such as the acute phase may induce the appearance of these antibodies as previously demonstrated [2].

Conflict of interest None.

\section{References}

1. Camargo EW, Freire PV, Silva CA, Santos NR, Mota2 LM, Pereira RM, de Carvalho JF (2011) Antiphospholipid syndrome plus rheumatic fever: a higher risk factor for stroke? Rheumatol Int (in press)

2. Figueroa F, Berríos X, Gutiérrez M, Carrión F, Goycolea JP, Riedel I, Jacobelli S (1992) Anticardiolipin antibodies in acute rheumatic fever. J Rheumatol 19:1175-1180

3. Blank M, Krause I, Magrini L, Spina G, Kalil J, Jacobsen S, Thiesen HJ, Cunningham MW, Guilherme L, Shoenfeld Y (2006) Overlapping humoral autoimmunity links rheumatic fever and the antiphospholipid syndrome. Rheumatology (Oxford) 45:833-841

4. Guidelines for the diagnosis of rheumatic fever. Jones Criteria, 1992 update (1992) Special Writing Group of the Committee on Rheumatic Fever, Endocarditis, and Kawasaki Disease of the Council on Cardiovascular Disease in the Young of the American Heart Association. JAMA 268:2069-2073

5. Harris EN, Pierangeli S (1991) The anticardiolipin ELISA test. Clin Immunol Newsletter 11:33-44

6. Wisloff F, Jacobsen EM, Liestol S (2002) Laboratory diagnosis of the antiphospholipid syndrome. Thromb Res 108:263-271 